\title{
Aspects of the affective disorders and the affective temperaments in medical students from Rostov-on-Don, Russia
}

\author{
Maxim Dmitriev ${ }^{1,2, *}$, Ekaterina Nikitenko $^{3}$, Maria Mamedova $^{2}$, Nikita $_{\text {Spryshkov }}^{2}$ \\ ${ }^{1}$ Don State Technical University, Rostov-on-Don, 344010, Russia \\ ${ }^{2}$ Rostov State Medical University, Rostov-on-Don, 344022, Russia \\ ${ }^{3}$ School 499, Saint-Petersburg, 195112, Russia
}

\begin{abstract}
Affective disorders are widespread among student youth. Anxiety and depression are the most common disorders, but thorough diagnostics reveals other emotional disturbances as well, which may imply bipolar disorder (BD). BD is associated with a wide range of adverse outcomes; therefore, it is important to identify masking symptoms that predict the onset and course of BD. One of the predictors of bipolar disorder is the temperament. The present study aimed to analyze the entire spectrum of affective disorders and determine the correlation between them and the affective temperaments. The study involved 106 medical students. They completed the following autoquestionnaires: PHQ-9, ASRM, GAD-7, ShARS, HCL-32 and TEMPS-A. Conducting analyses, the results of the HCL-32 questionnaire were statistically significantly correlating with the results of GAD-7 $(p=0.034)$ and the hyperthymic $(p=0.000)$, cyclothymic $(p=0.000)$ and excitable $(p=0.004)$ temperaments according to TEMPSA. When dividing the total sample into two groups, based on the HCL-32 questionnaire data, a higher incidence of depressive disorders on the PHQ9 scale $(\mathrm{p}=0.023)$ was found among respondents who scored more than 14 points on the HCL-32. of hypomania, which implies a high risk of developing bipolar spectrum disorders. A statistically significant relationship between hypomania and personality traits was found with hyperthymic, cyclothymic and excitable temperaments. It is necessary to diagnose such disorders in time to improve the social functioning of the students.
\end{abstract}

\section{Introduction}

Students as a social category are exposed to a complex of psycho-emotional factors. This contributes to a decrease in the general adaptive reserves of a person and can induce the appearance of psychosomatic and mental diseases [1]. Such disorders significantly affect social functioning, especially in learning. Among the most frequent manifestations of mental disorders, affective pathology takes the first place. Anxiety and depression are most often recorded $[2,3,4,5,6]$. The prevalence of these disorders among students significantly exceeds

\footnotetext{
* Corresponding author: dmitriev.max@mail.ru
} 
the general population indicators and reaches the level from $20 \%$ to $60 \%$ of respondents $[7,8,9,10,11]$ depending on study design.

Ethnic and cultural characteristics of the region should be taken into account when conducting psychometric studies. Hyperthymic temperament can be considered as a predisposing factor to the development of bipolar disorder. Hyperthymic temperament was more common in healthy people in countries where the language is similar in linguistic structure to Russian, for example, in Bulgaria. [12]. There is a number of studies on medical students in Russia, where the frequency of detection of hypomania by The Hypomania Checklist (HCL-32) exceeded 50\%. [4,11,13,14,15]. Frequent comorbidity of anxiety disorders was found in medical students with hypomania. This may indicate a high risk of mixed affective states as sign of bipolar spectrum disorders. The criteria for the maturity of emotional reactions are their adequacy to the situation, the consistency of behavior and the emotional state of the individual, the success of self-regulation, which allows maintaining social adaptability. In Russia, many regional centers conduct studies that reveal a significant frequency of mental disorders in medical students, among which bipolar spectrum disorders predominate $[4,5,6,11,13,14,15]$.

It can be latent for several years, masked as personal or neurotic stress induced experiences.

The predominance of a shallow non-psychotic level of affect in young people and formalized indications of the presence of regular stress loads, the continuing formation of personality traits and ideological attitudes can mask the onset of a deeper mental disorder. Often, manifestations of borderline disorder or personality sharpness are predictors of bipolar disorder $[16,17,18]$. Comorbid with anxiety and depression, disorders from the range of psychosomatic pathology, typical for bipolar spectrum disorders, are often found. Students often show manifestations of chemical and non-chemical dependence, certain eating disorders $[13,14,19,20,21,22]$.

The correct qualification of affective pathology at the non-psychotic level is very significant. BD is associated with a wide range of adverse health and social outcomes, including high suicide rates, frequent relapses of psychosis, and readmission to hospital. Therefore, it is important to identify masking manifestations that predict the onset and course of bipolar disorder, so that preventive measures and well-timed therapy can be taken $[16,23]$.

Difficulties exist in correctly recognizing bipolar disorder without clear emotional and behavioral signs of a manic component. Since anxious and depressive experiences are subjectively hard, they are perceived by a person as painful. Such people are easy enough to identify during any survey or they themselves seek help. The prevalence of subpsychotic and psychotic levels of depressive experiences is quite high among students. Moderate and severe depression was found in $6.9-9 \%$ of students $[10,24]$, which is a significant risk factor for suicide [9].

The manifestations of hypomania by young people are often regarded as manifestations of success, high level of health and good adaptation. Therefore, such people themselves practically never complain about the symptoms of hypomania. Its signs can be identified with a special study. Detection of hypomania can change the perception of the diagnosis of affective or anxiety disorder [25]. Among young people, such disorders are quite common, but are recognized mainly retrospectively. For example, $85.7 \%$ of UK female students with a previously diagnosed depression show signs of hypomania [26], suggesting a probable diagnosis of bipolar disorder. Identification and careful analysis of bipolar disorders spectrum is considered to be more important problem than psychologisation of any affects. Therefore, the staged research of affective pathology spectrum in future doctors is held over a number of years in Rostov State Medical University [4,11,13,14].

The aim of this study was to identify the spectrum of affective disorders and types of affective temperaments in medical students. identifying emotional disorders in the subjects 
in the form of depression, mania, anxiety at the current moment, determining anamnestic signs of hypomania, indicating a possible bipolar affective disorder, assessing the relationship between the identified disorders. We also compared emotional disorders with affective temperament, which is one of the predictors of affective spectrum disorders. This study is actual from the point of view of an objective understanding of the state of mental health of future doctors.

\section{Materials and methods}

The study involved 106 fifth-year students (34 of them - males and 72 - females) of the Rostov State Medical University. The average age of the subjects was 22 years. All students signed a voluntary informed consent to take a survey and to process data. As research methods, we used psychometric tests related to auto-questioning. The clinical manifestations of depression were studied using the Depression module of the Patient Health Questionnaire (PHQ-9) [27]. We used the Altman Self-Assessment Mania Scale (ASRM) [27] and the The Hypomania Checklist (HCL-32) [29] to assess the manic radical. Generalized Anxiety Disorder Rating Scale (GAD-7) [30] and the Sheehan Anxiety Rating Scale (ShaRS) [31,32] were used to detect paroxysmal anxiety to identify anxiety disorders. To determine the affective temperament, the TEMPS-A method (The Temperament Evaluation Memphis, Pisa, Paris and San Diego Auto-questionnaire) was used [33]. A feature of this study can be considered the use of exclusively auto-questionnaires, which increases the reliability of the results. The results obtained were summarized in an Excel table and the data were processed using the SPSS 23.0 program using the nonparametric Mann-Whitney test for two independent samples and linear r-Pearson correlation coefficient.

\section{Results}

To clarify the homogeneity of the sample, we divided the subjects into two groups according to gender in order to identify significant differences. The first group consisted of males - 34 students $(32.07 \%)$. The second group - females - 72 people $(67.92 \%)$. Table 1 shows the mean values and standard deviations for both groups for each of the questionnaires. The obtained mean values were compared by the nonparametric Mann-Whitney test for two independent samples.

Table 1. Statistics of groups divided by gender.

\begin{tabular}{|c|c|c|c|}
\hline Questionnaire & & $\begin{array}{l}\text { Males } \\
(\mathrm{n}=34)\end{array}$ & Females $(n=72)$ \\
\hline \multirow{3}{*}{$\begin{array}{l}\text { 1. PHQ-9 (Depression } \\
\text { module of the Patient } \\
\text { Health Assessment } \\
\text { Questionnaire) }\end{array}$} & $\begin{array}{l}\text { Number of subjects with } \\
\text { impairments }\end{array}$ & $22(64.7 \%)$ & $48(66.6 \%)$ \\
\hline & Mean & 9.030 & 6.6402 \\
\hline & Significance level $p$ & \multicolumn{2}{|c|}{0.175} \\
\hline \multirow{3}{*}{$\begin{array}{l}\text { 2. ASRM (Altman Self- } \\
\text { Assessment Mania Scale) }\end{array}$} & $\begin{array}{l}\text { Number of subjects with } \\
\text { impairments }\end{array}$ & $7(20.5 \%)$ & $27(37.5 \%)$ \\
\hline & Mean & 3.333 & 4.290 \\
\hline & Significance level $p$ & \multicolumn{2}{|c|}{0.070} \\
\hline \multirow{3}{*}{$\begin{array}{l}\text { 3. GAD-7 (Generalized } \\
\text { Anxiety Disorder Rating } \\
\text { Scale) }\end{array}$} & $\begin{array}{l}\text { Number of subjects with } \\
\text { impairments }\end{array}$ & $23(67.6 \%)$ & $28(38.8 \%)$ \\
\hline & Mean & 5.242 & 3.2407 \\
\hline & Significance level $p$ & \multicolumn{2}{|c|}{$0.038 *$} \\
\hline \multirow{2}{*}{$\begin{array}{l}\text { 4. ShaRS (Sheehan } \\
\text { Anxiety Rating Scale) }\end{array}$} & $\begin{array}{l}\text { Number of subjects with } \\
\text { impairments }\end{array}$ & $4(11.76 \%)$ & $15(20.83 \%)$ \\
\hline & Mean & 11.121 & 15.852 \\
\hline
\end{tabular}




\begin{tabular}{|l|l|c|c|}
\hline & Significance level $\mathrm{p}$ & \multicolumn{2}{|c|}{0.354} \\
\hline \multirow{4}{*}{5. HCL-32 } & $\begin{array}{l}\text { Number of subjects with } \\
\text { impairments }\end{array}$ & $20(58.8 \%)$ & $28(38.8 \%)$ \\
\cline { 2 - 4 } & Mean & 15.182 & 13.043 \\
\cline { 2 - 4 } & Significance level p & \multicolumn{2}{|c|}{0.182} \\
\hline Note: * significance level p is 0.05
\end{tabular}

In both groups (both males and females), depressive spectrum disorders were often clinically manifested - they were detected in $64.7 \%$ of males and $66.6 \%$ of females. Generalized anxiety disorders in females were much less common $(38.8 \%)$. On the other hand, among the men tested, anxiety disorders were more common than any other affective disorders. In addition, when comparing the means according to the statistical nonparametric Mann-Whitney test for two independent samples, the indicators of anxiety (on the GAD-7 scale) were significantly higher in males than in females $(p=0.038)$. For the rest of the scales, no statistically significant differences were found between the two groups.

To clarify the links between the HCL-32 questionnaire indices with the results of other scales used to identify affective disorders, an analysis of the correlations between these scales was carried out - we used the Pearson's correlation coefficient. Also included in this analysis were the results of the Affective Temperaments Questionnaire TEMPS-A. The results obtained are shown in Table 2.

Table 2. Correlation analysis between the results of the HCL-32 questionnaire, other scales for detecting affective pathology and the results of TEMPS-A.

\begin{tabular}{|l|c|c|}
\hline & $\begin{array}{c}\text { Pearson's correlation } \\
\text { coefficient Significance level } \\
\mathbf{p}\end{array}$ & $\begin{array}{c}\text { Pearson's correlation } \\
\text { coefficient Significance } \\
\text { level p }\end{array}$ \\
\hline GAD-7 - Rating Scale & $0.206^{*}$ & 0.034 \\
\hline & & 0.000 \\
\hline Hyperthymic temperament & $0.406^{* *}$ & 0.000 \\
\hline Cyclothymic temperament & $0.376^{* *}$ & 0.004 \\
\hline Irritable temperament & $0.296^{* *}$ & \\
\hline $\begin{array}{l}\text { Note: } * \text { significance level } p \text { is } 0.05 \\
* * \text { significance level } p \text { is } 0.01\end{array}$ & \\
\hline
\end{tabular}

Correlation analysis revealed a statistically significant relationship between a history of hypomania episodes and generalized anxiety, which suggests the development of mixed affective states, indicating bipolar spectrum disorder.

The most pronounced correlation coefficient was obtained between HCL-32 and hyperthymic temperament $(\mathrm{k}=0.406 \mathrm{p}=0.000)$, slightly lower correlation coefficient with cyclothymic temperament $(\mathrm{k}=0.376 \mathrm{p}=0.000)$ and a slight correlation is observed with excitable temperament $(\mathrm{k}=0.296 \mathrm{p}=0.004)$. These statistically significant relationships make it possible to more clearly reflect the features of the anamnestic periods of hypomania in respondents. To a greater extent, HCL-32 indicators are associated with manifestations of the type of hyperthymic temperament than cyclothymic and excitable. These results demonstrate statistically significant correlation between TEMPS-A affective temperaments and affective disorders among surveyed.

Subsequently, in order to identify affective disorders of the bipolar spectrum, we divided the subjects on the basis of HCL-32, a questionnaire that reveals a history of hypomania. So, indicators of 14 points and higher were revealed in 48 students, which is $45.28 \%$. These respondents made up the first study group - HCL-32 +. The second group (HCL-32-) consisted of students with no history of hypomania, who scored less than 14 points on the HCL-32 scale. There were 58 such subjects (54.71\% of the total sample). Further analysis of the results was carried out in these groups. 
Quantitative data on the frequency of occurrence of the affective pathology under consideration are given in Table 3 . The percentage indicates the frequency of occurrence of affective disorders relative to the number of subjects in each group.

Table 3. Quantitative data on the incidence of affective pathology in medical students, divided by the bipolarity index.

\begin{tabular}{|c|c|c|c|}
\hline Quetinnaire & Sample (n=106) & $\begin{array}{c}\text { Group 1 - HCL-32+ } \\
(\mathbf{n}=\mathbf{4 8})\end{array}$ & $\begin{array}{c}\text { Group 2 - HCL-32- } \\
(\mathbf{n}=\mathbf{5 8})\end{array}$ \\
\hline PHQ-9 & $70(66.03 \%)$ & $35(72.9 \%)$ & $35(60.3 \%)$ \\
\hline ASRM & $34(32.07 \%)$ & $15(31.25 \%)$ & $19(32.75 \%)$ \\
\hline GAD-7 & $51(48.11 \%)$ & $27(56.25 \%)$ & $24(41.37 \%)$ \\
\hline ShaRS & $19(17.9 \%)$ & $8(16.6 \%)$ & $11(18.9 \%)$ \\
\hline
\end{tabular}

A statistical analysis of these data in SPSS was carried out - a comparison of the means by the nonparametric Mann-Whitney test for two independent samples. The results are shown in Table 4.

Table 4. Statistical analysis of groups divided by bipolarity index.

\begin{tabular}{|l|c|c|c|}
\hline & $\begin{array}{c}\text { Mean group 1. } \\
\text { HCL+ (HCL-32 }> \\
\text { 14) (n= 48) }\end{array}$ & $\begin{array}{c}\text { Mean group 2. } \\
\text { HCL- (HCL-32 } \\
<\mathbf{1 4})(\mathbf{n}=\mathbf{5 8})\end{array}$ & Significance level p \\
\hline $\begin{array}{l}\text { PHQ-9 (Depression } \\
\text { module of the Patient } \\
\begin{array}{l}\text { Health Assessment } \\
\text { Questionnaire) }\end{array}\end{array}$ & 8.521 & 6.327 & $0.023^{*}$ \\
\hline $\begin{array}{l}\text { Hyperthymic } \\
\text { temperament } \\
\text { TEMPS-A }\end{array}$ & 8.372 & 5.86 & $0.000^{* *}$ \\
\hline $\begin{array}{l}\text { Cyclothymic } \\
\text { temperament } \\
\text { TEMPS-A }\end{array}$ & 6.883 & 4.571 & $0.002^{* *}$ \\
\hline $\begin{array}{l}\text { Note: * significance level } p \text { is } 0.05 \\
* * \text { significance level } p \text { is } 0.01\end{array}$ & & \\
\hline
\end{tabular}

\section{Discussion}

The high incidence of hypomania (45.3\%) on the HCL-32 scale, characteristic of type II bipolar disorder, indicates the presence of latent bipolar spectrum disorders in almost half of the respondents.

Disorders of the depressive spectrum are quite common both in the general sample $(66.03 \%)$ and in each of the groups (72.9\% and $60.3 \%$ in the first and second HCL-32 groups, respectively), which significantly exceeds the general population level. But these results are comparable with the data of previous studies carried out both in Rostov State Medical University and in other educational institutions [11,13,14,34]. Statistical analysis revealed a statistically significant predominance $(\mathrm{p}=0.023)$ of clinical depression in group 1 , which indicates that half of the respondents with depressive symptoms may have bipolar spectrum disorders. We found a relatively shallow degree of affective pathology in the majority of respondents, the presence of social adaptation - they all continued their studies at the university. These signs indicate a soft bipolar spectrum and allow typing the detected mental 
disorders as probable manifestations of cyclothymia or Bipolar Affective Disorder of the second type (BD-II) [35,36].

Anxiety disorders were found to be less common than depressive disorders. When analyzing the manifestations of generalized and paroxysmal anxiety, no statistically significant difference was found between the comparison groups. But the correlation analysis showed a statistically significant relationship between the presence of hypomania and generalized anxiety, which indicates a high likelihood of developing bipolar spectrum disorders in students with symptoms of anxiety disorders. At the same time, alarming manifestations can act not as an independent type of psychosomatic pathology, but as part of the BD phenotype $[37,38]$.

The results obtained do not repeat the results of past similar studies at the Rostov Medical University $[11,13,14]$, in which generalized anxiety was significantly more common in groups of students with high HCL-32 scores. This discrepancy may be due to the insufficient number of respondents with impairments in GAD-7 and ASRM in the groups divided on the basis of the HCL-32 questionnaire.

Also, in the first group (HCL-32 + ), higher values of hyperthymic $(\mathrm{p}=0.000)$ and cyclothymic ( $p=0.002)$ temperaments according to TEMPS-A were revealed. That is, respondents with indicators of hypomania above the normative symptomatic states and reactions are noted not only during periods of hypomanic rises, but in general characterize the predisposition of these people to certain types of emotional response.

\section{Conclusions}

The conducted research has shown a high frequency of affective spectrum disorders among students of Rostov State Medical University. Most often, the respondents had depressive disorders $(66.03 \%)$. The next most common in this sample was generalized anxiety - it was found in $48 \%$ of respondents. It is also noteworthy that many students had clinical manifestations characteristic of bipolar spectrum disorders $-45.28 \%$ of respondents had a history of hypomania according to the HCL-32 questionnaire. We found a comorbidity of high rates of depression, anxiety and hypomania in $14 \%$ of the subjects at the same time, which indicates a high risk of developing bipolar disorder. Also, a statistically significant relationship was revealed between the presence of hypomania in the anamnesis and hyperthymic and cyclothymic temperaments, which confirms the predisposition of such people to a certain type of emotional response.

The timely detection and correction of such disorders can alleviate both the medical and social consequences of affective disorders - the psychosocial and educational functioning of students is improved. In the future, further studies are planned with a larger number of respondents to obtain more statistically significant data.

\section{Acknowledgements}

All authors initiated, designed and conducted the study. All authors contributed to interpretation of the data and writing the paper. All authors read and approved the final manuscript. All authors have made equal contributions.

Competing interests. The authors declare that there are no competing interests.

\section{References}

1. N. Azad, A. Shahid, N. Abbas, A. Shaheen, N. Munir, Journal of Ayub Medical College, Abbottabad: JAMC 29(1), 123-127 (2017) 
2. L.N. Dyrbye, M.R. Thomas, T.D. Shanafelt, Academic medicine : journal of the Association of American Medical Colleges 81(4), 354-373 (2006) https://doi.org/10.1097/00001888-200604000-00009

3. A.V. Semke, V.N. Shadrin, Sibirskij vestnik psichiatrii i narkologii, 51-54 (2012)

4. M.N. Dmitriev, XVI s"ezd psihiatrov Rossii. Vserossiǔskaya nauchno-prakticheskaya konferenciya s mezhdunarodnym uchastiem «Psihiatriya na etapah reform: problemy $i$ perspektivy»: tezisy ( $\mathrm{SPb}, 2015)$

5. M.A. Kulygina, D.M. Carenko, M.V. Semiglazova, XVI s"ezd psihiatrov Rossii. Vserossiüskaya nauchno- prakticheskaya konf. s mezhdunar. uchastiem «Psihiatriya na etapah reform: problemy i perspektivy»: tezisy ( $\mathrm{SPb}, 2015)$

6. E.V. Derevyannyh, N.A. Balashova, R.A. YAskevich, O.L. Moskalenko, Siberian Journal of Life Sciences and Agriculture 9(1), 10-28 (2017)

7. W. Zeng, R. Chen, X. Wang, Q. Zhang, W. Deng, Medicine 98(18), e15337 (2019) https://doi.org/10.1097/MD.0000000000015337

8. C. Liu, L. Wang, R. Qi, et al, Psychology research and behavior management 12, 195208 (2019) https://doi.org/10.2147/PRBM.S195131

9. L.S. Rotenstein, M.A. Ramos, M. Torre, et al, JAMA 316(21), 2214-2236 (2016) https://doi.org/10.1001/jama.2016.17324

10. K.W. Lun, C.K. Chan, P.K. Ip, et al, Hong Kong medical journal 24(5), 466-472 (2018) https://doi.org/10.12809/hkmj176915

11. M.N. Dmitriev, E.A. Nikitenko, A.N. Sannikov, E.N. Kovaleva, Materialy Mezhdunarodnogo Nauchnogo Kongressa «Medicinskie $i$ biologicheskie nauki: dostizheniya i perspektivy» (Tanzaniya, 2018)

$\begin{array}{lll}\text { 12. P. Marinova, Neuropsychopharmacology 23(2), } & \text { 372-373 }\end{array}$ https://doi.org/10.1016/S0924-977X(13)70588-1

13. T.V. Dunajceva, E.M. Macyuk, E.V. Obrazcova, A.F. Hejgetyan, 73-ya itogovaya nauchnaya konferenciya studentov Rostovskogo Gosudarstvennogo Medicinskogo Universiteta - sbornik materialov, 179-180 (2019)

14. T.V. Dunajceva, E.M. Macyuk, E.V. Obrazcova, A.F. Hejgetyan, I.S. Ismailov, Somatonevrologia - materialy mezdhunarodnoj nauchno-prakticheskoj konferencii studentov i molodyh uchenyh, 21-32 (2019)

15. T.Y. Grechko, T.S. Bulgakova, Nauchno-medicinskij vestnik Central'nogo Chernozem'ya 59, 40-43 (2015)

16. T.H. Ng, T.A. Burke, J.P. Stange, et al, Journal of abnormal psychology 126(3), 271284 (2017) https://doi.org/10.1037/abn0000255

17. S. Yen, E. Frazier, H. Hower, et al, Acta psychiatrica Scandinavica 132(4), 270-280 (2015) https://doi.org/10.1111/acps.12415

18. J.B. Edgcomb, B. Kerner, Journal of affective disorders 227, 681-687 (2018) https://doi.org/10.1016/j.jad.2017.11.083

19. P.M. Bhandari, D. Neupane, S. Rijal, K. Thapa, S.R. Mishra, A.K. Poudyal, BMC psychiatry 17(1), 106 (2017) https://doi.org/10.1186/s12888-017-1275-5

20. T.D. Meyer, L. Wolkenstein Compr Psychiatry 51(2), 171-176 (2010) http://dx.doi.org/10.1016/j.comppsych.2009.05.002

21. C.S. Tang, Y.Y. Koh, Asian journal of psychiatry 25, 175-178 (2017) https://doi.org/10.1016/j.ajp.2016.10.027 
22. Ł. Mokros, A. Witusik, J. Michalska, W. Łężak, M. Panek, K. Nowakowska-Domagała, A. Antczak, T. Pietras, Chronobiology international 34(6), 708-720 (2017) https://doi.org/10.1080/07420528.2017.1316730

23. R.P. Auerbach, J. Alonso, W.G. Axinn, P. Cuijpers, D.D. Ebert, J.G. Green, Et al., Psychological medicine 46(14), 2955-2970 (2016) https://doi.org/10.1017/S0033291716001665

24. D.D. Ebert, C. Buntrock, P. Mortier, R. Auerbach, K.K. Weisel, R.C. Kessler, et al., Depression and anxiety 36(4), 294-304 (2019) https://doi.org/10.1002/da.22867

25. J. Angst, C. Grobler, European archives of psychiatry and clinical neuroscience 265(4), 273-280 (2015) https://doi.org/10.1007/s00406-015-0577-1

26. T. Richardson, H. Garavan, Clinical practice and epidemiology in mental health: CP \&

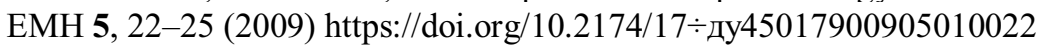

27. F. Borghero, V. Martínez, P. Zitko, P.A. Vöhringer, G. Cavada, G. Rojas, Revista medica de Chile 146(4), 479-486 (2018) https://doi.org/10.4067/s003498872018000400479

28. E. Altman, Journal of affective disorders 50(2-3), 283-286 (1998) https://doi.org/10.1016/s0165-0327(98)00018-4

29. T.D. Meyer, E. Castelao, M. Gholamrezaee, J. Angst, M. Preisig, Acta psychiatrica Scandinavica 135(6), 539-547 (2017) https://doi.org/10.1111/acps.12715

30. B. Löwe, O. Decker, S. Müller, E. Brähler, D. Schellberg, W. Herzog, P.Y. Herzberg, Medical care 46(3), 266-274 (2008) https://doi.org/10.1097/MLR.0b013e318160d093

31. D.V. Sheehan, The anxiety disease (Scribers, New York, 1983)

32. O.V. Barkanova, Biblioteka aktual'noy psychologii 2, 237 (2009)

33. G.H. Vázquez, H. Akiskal, The temperament evaluation of the Memphis, Pisa, Paris, and San Diego autoquestionnaire, Argentine version (TEMPS-A Buenos Aires) 16(60), 8994 (2005)

34. M.A. Rogozina, S.N. Podvigin, E.A. Semenov, Y.E. Mishchuk, Nauchno-medicinskij vestnik Central'nogo CHernozem'ya 41, 59-62 (2010)

35. G. Perugi, H.S. Akiskal, The Psychiatric clinics of North America 25(4), 713-737 (2002) https://doi.org/10.1016/s0193-953x(02)00023-0

36. A.R. Van Meter, E.A. Youngstrom, B. Birmaher, et al, Journal of affective disorders 215, 314-322 (2017) https://doi.org/10.1016/j.jad.2017.03.019

37. G.H. Vrazquez, R.J. Baldessarini, L. Tondo, Depression Anxiety 31, 196-206 (2014) https://doi.org/10.1002/da.22248

38. R. Jain, V. Maletic, R.S. McIntyre, The Journal of clinical psychiatry 78(8), 1091-1102 (2017) https://doi.org/10.4088/JCP.su17009ah1c 